\title{
Reply to comment by $T$. Mölg et al. on "Recent glacial recession in the Rwenzori Mountains of East Africa due to rising air temperature"
}

\author{
Richard G. Taylor, ${ }^{1}$ Lucinda Mileham, ${ }^{1}$ Callist Tindimugaya, ${ }^{2}$ Abushen Majugu, ${ }^{3}$ \\ Andrew Muwanga, ${ }^{4}$ and Bob Nakileza ${ }^{5}$ \\ Received 24 July 2006; revised 11 September 2006; accepted 12 September 2006; published 28 October 2006.
}

Citation: Taylor, R. G., L. Mileham, C. Tindimugaya, A. Majugu, A. Muwanga, and B. Nakileza (2006), Reply to comment by T. Mölg et al. on "Recent glacial recession in the Rwenzori Mountains of East Africa due to rising air temperature", Geophys. Res. Lett., 33, L20405, doi:10.1029/2006GL027606.

[1] Debate persists as to the extent to which recent glacial recession observed in tropical highlands is driven primarily by changes in air temperature [e.g., Bradley et al., 2006; Thompson et al., 2006] and atmospheric humidity [e.g. Kaser et al., 2004; Mölg and Hardy, 2004]. Uncertainty has also been expressed in the relationship between temperature trends at the surface and higher elevations in the tropical free troposphere [e.g., Christy et al., 2003; Christy and Norris, 2004; Douglass et al., 2004; Fu et al., 2004; Tett and Thorne, 2004] where alpine glaciers reside. We therefore welcome the constructive comments of Mölg et al. [2006] regarding our original paper and appreciate the opportunity to clarify arguments made therein [Taylor et al., 2006]. We agree with Mölg et al. that the surface energy balance and mass balance are best able to describe the relationship between climate parameters and glacier change [e.g., Wagnon et al., 1999; Mölg and Hardy, 2004]. For the Rwenzori Mountains, measurements that would form the basis of a glacier mass balance model do not exist. This point was recognized explicitly in the original paper, "The absence of continuous and proximate meteorological observations in the Rwenzori Mountains prevents direct analysis of the climatic factors driving observed glacial recession." Although a definitive, quantitative understanding of the climate variables responsible for glacier mass losses in the Rwenzori Mountains remains elusive, we dispute the assertion of Mölg et al. that air temperature $\left(T_{a}\right)$ is unlikely to be the main driver of observed glacial recession and argue that trends of increasing air temperature are better supported by currently available evidence than decreasing humidity posited by Mölg et al.

[2] The essential scientific criticism of our paper by Mölg et al. [2006] is the validity of the assumption that $T_{a}$ trends observed in gridded CRU TS 2.0 climate data sets [New et al.,

\footnotetext{
${ }^{1}$ Department of Geography, University College London, London, UK.

${ }^{2}$ Water Resources Management Department, Directorate of Water Development, Entebbe, Uganda.

${ }^{3}$ Meteorology Department, Ministry of Lands, Water and Environment, Kampala, Uganda.

${ }^{4}$ Department of Geology, Makerere University, Kampala, Uganda.

${ }^{5}$ Department of Geography, Makerere University, Kampala, Uganda.
}

Copyright 2006 by the American Geophysical Union. 0094-8276/06/2006GL027606\$05.00
2002] and at meteorological stations between 960 and 1869 meters above sea level (masl), reflect $T_{a}$ trends in the middle troposphere (4800 to 5100 masl) where glaciers in the Rwenzori Mountains occur. Mölg et al. suggest that we have disregarded evidence of inconsistencies between $T_{a}$ trends at the surface and in the tropical troposphere, but the literature [Hense et al., 1988; Gaffen et al., 2000; Bradley et al., 2004] and evidence they cite is selective. Significant uncertainty persists in temperature data for the tropical troposphere whether these derive from satellite-borne Microwave Sounding Unit (MSU) observations or in situ measurements using radiosondes, particularly in data-poor regions like East Africa. Indeed, linear $T_{a}$ trends in the tropical troposphere can vary significantly based simply upon choice of start and end date as is the case in the paper by Gaffen et al. [2000] using MSU data in which at $500 \mathrm{hPa}$ a cooling trend is detected between 1979 and 1997 but an overall warming trend occurs between 1960 and 1997. Nevertheless, recent studies that employ diurnal corrections to MSU observations between 1979 and 2003 [Mears and Wentz, 2005] and homogenized radiosonde data sets (HadAT2) between 1958 and 2002 [Thorne et al., 2005], show that the middle troposphere warmed at a similar or slightly greater rate to the surface in the tropics [Fu and Johanson, 2005; Santer et al., 2005], consistent with the sign and (within error) magnitude of $T_{a}$ trends $\left(+0.13^{\circ} \mathrm{C}\right.$ per decade) at the surface from climate model (HadCRU2v) predictions [Jones and Moberg, 2003].

[3] Mölg et al. [2006] use NCEP reanalysis data [Kalnay et al., 1996] for the grid cell $\left(30^{\circ} \mathrm{E}, 0^{\circ} \mathrm{N}\right)$ to support their claim that a discrepancy exists between $T_{a}$ trends at the lower troposphere $(850 \mathrm{hPa})$ and mid-troposphere $(600 \mathrm{hPa})$ in the Rwenzori Mountains (their Figure 1). There is, however, widespread consensus within the climate community that reanalysis data are unsuitable for trend analysis in climate change studies as "...known discontinuities in reanalyzed data sets indicate that further research is required to reduce time-dependent errors to a level suitable for climate change studies" [Intergovernmental Panel on Climate Change, 2001, p. 120]. The existence of systematic, time-varying biases in reanalysis data is also highlighted by more recent studies [Bengtsson et al., 2004; Simmons et al., 2004; Sterl, 2004; Thorne et al., 2005]. Mölg et al. consider biases in the NCEP data associated with the introduction of satellite observations in 1979 to reanalysis data sets (see caption in their Figure 1) but not other inconsistencies that arise from the wide range of data sources including modeled processes [Pepin and Seidel, 2005]. In contrast to inferences drawn by Mölg et al. using NCEP data, upper air temperature records from gridded HadAT2 radiosonde data [Thorne et al., 2005] for the most proximate (and only) grid cell to the Rwenzori 


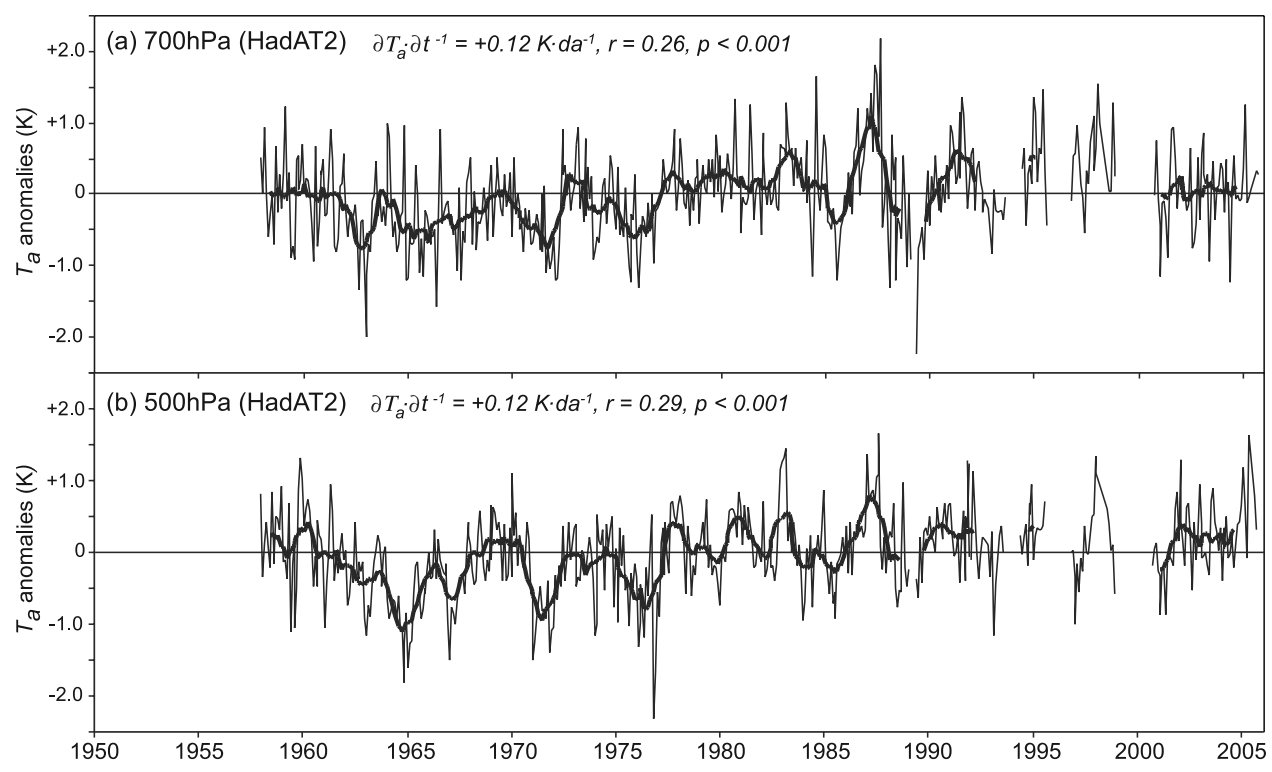

Figure 1. Time series of monthly air temperature anomalies in the lower and middle troposphere from homogenised radiosonde data sets (HadAT2) [Thorne et al., 2005] at (a) $700 \mathrm{hPa}$ and (b) $500 \mathrm{hPa}$ for the most proximate grid cell $\left(35^{\circ} \mathrm{E},-2.5^{\circ} \mathrm{S}\right)$ to the Rwenzori Mountains. Bold lines in Figures $1 \mathrm{a}$ and $1 \mathrm{~b}$ represent the 12 -month running mean.

Mountains show consistent warming trends in the lower and middle troposphere $(700 \mathrm{hPa}, 500 \mathrm{hPa})$ from 1958 to 2005 (Figure 1). These warming trends coincide with increased $T_{a}$ trends at the surface over the second half of the 20th century that have been detected in gridded (homogenized) CRU TS 2.0 data sets [New et al., 2002] at four locations in the East African Highlands by Pascual et al. [2006] and the Rwenzori Mountains [Taylor et al., 2006]. A comparison of temperature trends from surface observations at high elevations and free troposphere (radiosonde measurements) indicates more rapid warming of alpine surfaces than the free troposphere [Pepin and Seidel, 2005] though this discrepancy is reduced for mountain peaks and may stem from a systematic cooling bias arising from daytime heating of the radiosonde sensors [Sherwood et al., 2005]. Analyses of station data in the tropical Andes [Vuille and Bradley, 2000] and on the Tibetan Plateau [Liu and Chen, 2000] show that $\mathrm{T}_{\mathrm{a}}$ trends between 1000 and 5000 masl remain constant in sign (i.e., increasing $\mathrm{T}_{\mathrm{a}}$ ) but can vary in magnitude $\left(+0.1\right.$ to $+0.3^{\circ} \mathrm{C}$ per decade). It is worth noting that a step-wise increase in $\mathrm{T}_{\mathrm{a}}$ during the 1970s, noted globally at the surface [Jones and Moberg, 2003] and in the troposphere [Thorne et al., 2005] as well as in the tropical Andes [Vuille and Bradley, 2000], is also observed at the surface in CRU TS 2.0 data sets in the East African Highlands [Pascual et al., 2006, Figure 1] and station data in western Uganda [Taylor et al., 2006, Figure 3].

[4] Mölg et al. [2006] employ NCEP reanalysis data to indicate a trend of decreasing specific humidity in the midtroposphere $(600 \mathrm{hPa})$ from 1948 to 2005 . Quite apart from the time-dependent biases in all NCEP data, the reliability of the specific humidity data is particularly questionable as NCEP humidity is a statistically derived parameter. The ability of NCEP humidity data to represent interannual precipitation anomalies associated with the dominant modes of climate variability in equatorial east Africa, highlighted by Mölg et al. (their Figure 2), does not bear on the reliability of these data sets for trend analyses. Radiosonde-derived humidity from 1965 to 1984 [Hense et al., 1988] cited in support of NCEP specific humidity trends from 1948 to 2005, are in fact uncorrected; systemic dry biases have been carefully removed from more recent corrected data sets [Guichard et al., 2000]. A decline in humidity over the 20th century is, furthermore, unsupported by surface CRU TS 2.0 precipitation and vapour pressure data sets (Figure 2). Mölg et al. additionally argue that observed glacial recession in the East African Highlands over the last century originates from a drastic reduction in moisture in the late 19 th century. This drop in moisture, based on historical evidence of the levels of Lake Victoria and other East African lakes [Nicholson and Yin, 2001], is actually the descending limb of a brief, approximately decade-long high lake stand (Figure 3). Lake levels, a remote and indirect proxy of regional humidity, are variable during the

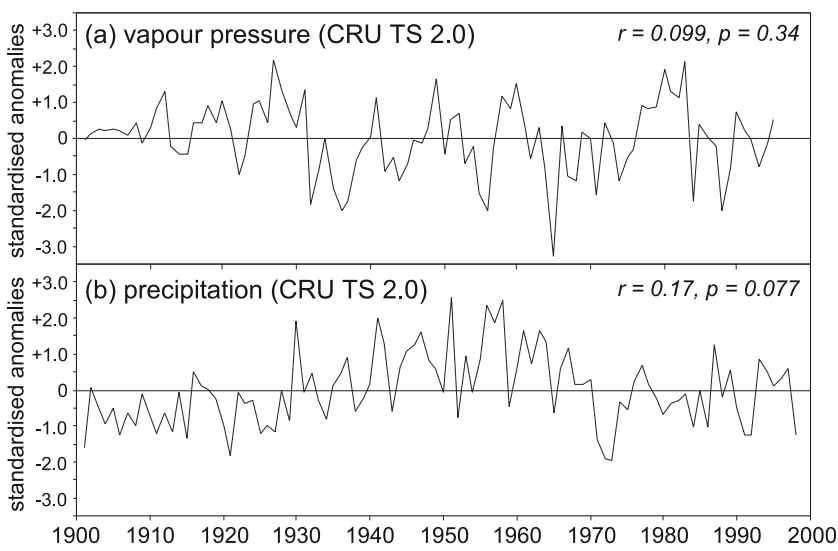

Figure 2. Time series of mean annual anomalies in (a) vapour pressure (1901 to 1995) and (b) precipitation (1901 to 1998) from gridded CRU TS 2.0 climate data [New et al., 2002] for the most proximate grid cell $\left(29.5^{\circ} \mathrm{E},+0.5^{\circ} \mathrm{N}\right)$ to the Rwenzori Mountains. 


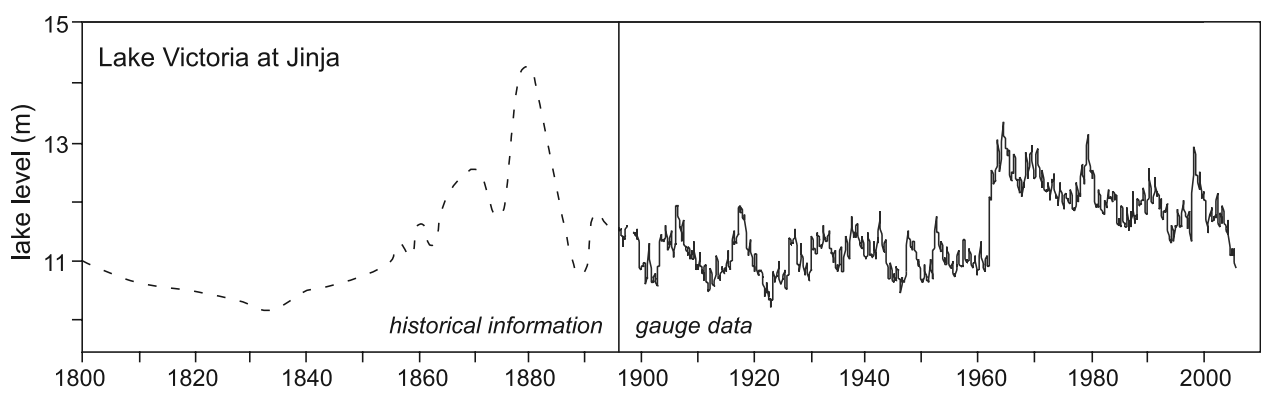

Figure 3. Level of Lake Victoria at Jinja $\left(33.2^{\circ} \mathrm{E}, 0.2^{\circ} \mathrm{N}\right)$ from 1800 to 2005 based on historical evidence from 1800 to 1896 [Nicholson and Yin, 2001] and monthly observations from 1896 to 2005.

19th century prior to their peak in 1880 but comparable to lake levels throughout the 20th century. A modern comparison to the 19th century event is the $2.3 \mathrm{~m}$ rise in the level of Lake Victoria between October 1961 and May 1964 (Figure 3). The implied increase in humidity associated with this lake-level rise coincides with a very brief (one year) and very marginal advance ( 3 to $5 \mathrm{~m}$ ) in the terminal positions of valley glaciers in the Rwenzori Mountains [Temple, 1968]. The humidity hypothesis proposed by Mölg et al. contends that (1) termination of a brief period of accumulation due to enhanced precipitation around 1880 led to continued glacial retreat into the latter half of the 20th century and (2) a trend of decreasing humidity, supported only by NCEP reanalysis data for which trend analysis is inappropriate, has driven glacial recession since 1970. Even ignoring concerns regarding this evidence, the argument that these climate events are responsible for the expected demise of small, fast-responding glaciers that have persisted for at least 5000 years [Thompson et al., 2006] is improbable.

[5] Mölg et al. [2006] highlight several limitations in our analysis of glacial extent in the Rwenzori Mountains from 1987 to 2003 using Landsat imagery and field surveys. These include compensation for terrain-induced effects and limited rigor in our discrimination of snow and glacial cover using Landsat imagery. Small discrepancies noted in the mapped extent of glaciers on Mount Speke in 2003 with previous assessments [Kaser and Osmaston, 2002] arise, in part, from errors introduced through the reconciliation of data sets with different datums (i.e., WGS-84, 1950 Arc). We welcome the new estimate of glacial extent in 2005 from Mölg et al. using a similar approach but employing recently available ASTER imagery. They report combined glacial extents on Mounts Stanley, Speke, and Baker that are slightly larger $\left(1.14 \pm 0.10 \mathrm{~km}^{2}\right)$ but within calculated error of our estimate in $2003\left(0.96 \pm 0.34 \mathrm{~km}^{2}\right)$. Despite Mölg et al.'s objections to our reporting of a steady rate of decline in glacial extent in the Rwenzori Mountains over the last century, the apparent linearity in rate of retreat over the 20 th century, which we acknowledge may partly result from the paucity of measurements, exists whether their analysis $\left(\mathrm{r}^{2}=0.997\right)$ or ours $\left(\mathrm{r}^{2}=0.999\right)$ is considered.

[6] Both increasing air temperature and reduced air humidity remain plausible and likely related hypotheses to explain recent glacial recession in the Rwenzori Mountains of East Africa. There is agreement that glaciers in the Rwenzori Mountains continue to recede at a rate of $\sim 0.5 \mathrm{~km}^{2}$ per decade and presently occupy a total area of $\sim 1 \mathrm{~km}^{2}$. There is also agreement that there are insufficient data to represent the complex interactions of radiant energy and heat at the glacier's surface and thus quantify the link between changes in climate variables and glacial mass in the Rwenzori Mountains. We maintain that there is currently greater evidence of trends of increasing air temperature than decreasing humidity to explain deglaciation in the Rwenzori Mountains. This conclusion does not preclude, however, the likelihood that changes in humidity and radiative fluxes associated with rising air temperatures, have also contributed to observed glacial recession.

\section{References}

Bengtsson, L., S. Hagemann, and K. I. Hodges (2004), Can climate trends be calculated from reanalysis data?, J. Geophys. Res., 109, D11111, doi:10.1029/2004JD004536.

Bradley, R. S., F. T. Keimig, and H. F. Diaz (2004), Projected temperature changes along the American cordillera and the planned GCOS network, Geophys. Res. Lett., 31, L16210, doi:10.1029/2004GL020229.

Bradley, R. S., M. Vuille, H. F. Diaz, and W. Vergara (2006), Threats to water supplies in the Tropical Andes, Science, 312, 1755-1756.

Christy, J. R., and W. B. Norris (2004), What may we conclude about global tropospheric temperature trends?, Geophys. Res. Lett., 31, L06211, doi:10.1029/2003GL019361.

Christy, J. R., R. W. Spencer, W. B. Norris, W. D. Braswell, and D. E. Parker (2003), Error estimates of version 5.0 of MSU-ASMU bulk atmospheric temperatures, J. Atmos. Oceanic Technol., 20, 613-629.

Douglass, D. H., B. D. Pearson, and S. F. Singer (2004), Altitude dependence of atmospheric temperature trends: Climate models versus observation, Geophys. Res. Lett., 31, L13208, doi:10.1029/2004GL020103.

Fu, Q., and C. M. Johanson (2005), Satellite-derived vertical dependence of tropical tropospheric temperature trends, Geophys. Res. Lett., 32, L10703, doi:10.1029/2004GL022266.

Fu, Q., C. M. Johanson, S. G. Warren, and D. J. Seidel (2004), Contribution of stratospheric cooling to satellite-inferred tropospheric temperature trends, Nature, 429, 55-58.

Gaffen, D. J., B. D. Santer, J. S. Boyle, J. R. Christy, N. E. Graham, and R. J. Ross (2000), Multidecadal changes in the vertical temperature structure of the tropical troposphere, Science, 287, 1242-1245.

Guichard, F., D. Parsons, and E. Miller (2000), Thermodynamic and radiative impact of the correction of sounding humidity bias in the tropics, J. Clim., $13,3615-3624$

Hense, A., P. Krahe, and H. Flohn (1988), Recent fluctuations of tropospheric temperature and water vapour content in the tropics, Meteorol. Atmos. Phys., 38, 215-227.

Intergovernmental Panel on Climate Change (2001), Climate Change 2001: The Scientific Basis: Contribution of Working Group I to the Third Assessment Report of the Intergovernmental Panel on Climate Change, edited by J. T. Houghton et al., 881 pp., Cambridge Univ. Press, New York.

Jones, P. D., and A. Moberg (2003), Hemispheric and large-scale surface air temperature variations: An extensive revision and an update to 2001, J. Clim., 16, 206-223.

Kalnay, E., et al. (1996), The NCEP/NCAR 40-year reanalysis project, Bull. Am. Meteorol. Soc., 77, 437-471.

Kaser, G., and H. H. Osmaston (2002), Tropical Glaciers, p. 207, Cambridge Univ. Press, New York.

Kaser, G., D. R. Hardy, T. Mölg, R. S. Bradley, and T. M. Hyera (2004), Modern glacier retreat on Kilimanjaro as evidence of climate change: Observations and facts, Int. J. Climatol., 24, 329-339. 
Liu, X., and B. Chen (2000), Climatic warming in the Tibetan Plateau during recent decades, Int. J. Climatol., 20, 1729-1742.

Mears, C. A., and F. J. Wentz (2005), The effect of diurnal correction satellitederived lower tropospheric temperature, Science, 309, 1548-1551.

Mölg, T., and D. R. Hardy (2004), Ablation and associated energy balance of a horizontal glacier surface on Kilimanjaro, J. Geophys. Res., 109 D16104, doi:10.1029/2003JD004338.

Mölg, T., H. Rott, G. Kaser, A. Fischer, and N. J. Cullen (2006), Comment on "Recent glacial recession in the Rwenzori Mountains of East Africa due to rising air temperature" by Richard G. Taylor, Lucinda Mileham, Callist Tindimugaya, Abushen Majungu, Andrew Muwaga, and Bob Nakileza, Geophys. Res. Lett., 33, L20404, doi:10.1029/2006GL027254.

New, M. G., et al. (2002), A high-resolution data set of surface climate for terrestrial land areas, Clim. Res., 21, 1-25.

Nicholson, S. E., and X. Yin (2001), Rainfall conditions in equatorial East Africa during the nineteenth century as inferred from the record of Lake Victoria, Clim. Change, 48, 387-398.

Pascual, M., J. A. Ahumada, L. F. Chaves, X. Rodó, and M. Bouma (2006), Malaria resurgence in the East African Highlands: Temperature trends revisited, Proc. Natl. Acad. Sci. U. S. A., 103, 5829-5834.

Pepin, N. C., and D. J. Seidel (2005), A global comparison of surface and free-air temperatures at high elevations, J. Geophys. Res., 110, D03104, doi:10.1029/2004JD005047.

Santer, B. D., et al. (2005), Amplification of surface temperature trends and variability in the tropical atmosphere, Science, 309, 1551-1556.

Sherwood, S. C., J. R. Lanzante, and C. L. Meyer (2005), Radiosonde daytime biases and late-20th century warming, Science, 309, 159-1556.

Simmons, A. J., P. D. Jones, V. da Costa Bechtold, A. C. M. Beljaars, P. W. Kållberg, S. Saarinen, S. M. Uppala, P. Viterbo, and N. Wedi (2004), Comparison of trends and low-frequency variability in CRU, ERA-40, and NCEP/NCAR analyses of surface air temperature, J. Geophys. Res., 109, D24115, doi:10.1029/2004JD005306.

Sterl, A. (2004), On the (in)homogeneity of reanalysis products, J. Clim., 17, 3866-3873

Taylor, R. G., L. Mileham, C. Tindimugaya, A. Majugu, A. Muwanga, and B. Nakileza (2006), Recent glacial recession in the Rwenzori Mountains of East Africa due to rising air temperature, Geophys. Res. Lett., 33, L10402, doi:10.1029/2006GL025962.

Temple, P. H. (1968), Further observations on the glaciers of the Ruwenzori, Geogr. Ann., Ser. A, 50, 136-150.

Tett, S., and P. Thorne (2004), Tropospheric temperature series from satellites, Nature, 432, doi:10.1038/nature03208.

Thompson, L. G., E. Mosley-Thompson, H. Brecher, M. Davis, B. León, D. Les, P.-N. Lin, T. Mashiotta, and K. Mountain (2006), Abrupt tropical climate change: Past and present, Proc. Natl. Acad. Sci. U. S. A., 103, $10,536-10,543$.

Thorne, P. W., D. E. Parker, S. F. B. Tett, P. D. Jones, M. McCarthy, H. Coleman, and P. Brohan (2005), Revisiting radiosonde upper air temperatures from 1958 to 2002, J. Geophys. Res., 110, D18105, doi:10.1029/2004JD005753.

Vuille, M., and R. S. Bradley (2000), Mean annual temperature trends and their vertical structure in the tropical Andes, Geophys. Res. Lett., 27, $3885-3888$

Wagnon, P., P. Ribstein, B. Francou, and B. Pouyaud (1999), Annual cycle of energy balance of Zongo Glacier, Cordillera Real, Bolivia, J. Geophys. Res., 104, 3907-3924.

A. Majugu, Meteorology Department, Ministry of Lands, Water, and Environment, P.O. Box 7025, Kampala, Uganda.

L. Mileham and R. G. Taylor, Department of Geography, University College London, Gower Street, London WC1E 6BT, UK. (r.taylor@geog.ucl.ac.uk)

A. Muwanga, Department of Geology, Makerere University, P.O. Box 7062, Kampala, Uganda.

B. Nakileza, Department of Geography, Makerere University, P.O. Box 7062, Kampala, Uganda.

C. Tindimugaya, Water Resources Management Department, Directorate of Water Development, P.O. Box 19, Entebbe, Uganda. 